\title{
Model of Decision Making in Motivating Employees and Managers
}

\author{
Martina Blaskova, Michal Bizik, Radoslav Jankal
}

\author{
University of Zilina \\ Univerzitna 8215/1, 01026 Zilina, Slovak Republic \\ E-mail.blaskova@fri.uniza.sk
}

cross $^{\text {ref }}$ http://dx.doi.org/10.5755/j01.ee.26.5.8727

\begin{abstract}
The article deals with issues of decision making with regard to motivation of employees and managers. In an introductive and theoretical part, attention is devoted to analysing opinions on motivation, motivating, and decision making. The motivation is understood as a dynamic phenomenon, full of many facts, positive and negative, subjective and objective, constant (static, invariable) and variable (changing dynamically). The decision making is understood as a process of postulating decisionmaking premises, conditions, restrictions and defining criteria, non-compromising consideration of positives, negatives, possibilities and impossibilities, chances and obstacles of every accepted solution, and determining the 'best' methods of achieving the 'best' solution. In the methodology part of paper, the most interesting result of testing assumption about the multi-criteria content and multiplicative effect in decision making, applied in motivating employees, are presented. This searching is done on the basis of our questionnaire survey performed on the sample of 1,946 respondents in the turn of 2012/2013. The assumption about the multi-criteria content and multiplicative effect in decision making applied in motivating employees was confirmed. In the application part, acquired results and used inspirational opinions of several other authors formed the basis for creation of verbal and graphical model of motivational decision making, or the model of motivating perceived with regard to the decision making process. The model characterises motivational decision-making as multicontent and multi-criteria process able to bring qualitative multiplications and synergies.
\end{abstract}

Keywords: Decision Making, Motivation, Motivating, Multiplication, Qualitative Multi-criteria Decision Making.

\section{Introduction}

A continual and perplexing problem facing researchers and practitioners is to disclose the reasons and/or causes of real knowledge that some employees perform better than others. To explain such differences, several important variables have been used, e.g. ability, instinct, and aspiration levels, as well as demographic factors. However, one issue that consistently captures the attention of researchers and managers alike is motivation (Gibson et al., 1997, p. 125).

Motivation is the most complicated phenomenon of the contemporary human potential/capital development and other behavioural sciences (e.g. psychology, sociology, management, organisational behaviour, human resource management, etc.). When searching motivation and the ways of influencing it desirably, it is important to know that "any behaviour must be caused by some combination of both internal and external factors. To motivate means 'to cause to move', and the first question is the question of causation" (Grusec et al., 1990, pp. 149-150). The motivation expresses psychological reasons, or causes of human behaviour (Blazek, 2014, p. 162). In these intentions, the motivation may be defined as psychological forces that determine the direction of a person's behaviour in an organisation, a person's level of effort, and a person's level of persistence in the face of obstacles (Joneset et al., 1998, p. 373).

Motivation is the energising of human behaviour, or, simply stated, the process of stimulating action (Kinard, 1988 , p. 262). However, motivation is not an end but should serve the objective of the organisation. The aim is to ensure a coordinated employee effort in keeping with corporate objectives (Frey \& Osterloh, 2010, p. 21). Objectives harmonisation or identification with (from the viewpoint of the motivation and motivating) is pointed out also by many other authors, (e.g. Bender et al., 2012; Hitka 2009; Armstrong, 2007; Clark, 2003; Wright, 2003; Koontz \& Weihrich, 1993; Maccoby, 1988; etc).

In terms of the development of managerial and behavioural sciences, it should be appropriate to seek parallels between the motivating as activating managerial process and other processes in the organisation. Therefore, in order to examine the parallels between motivating, planning, and decision making, it can be noted that the defining reasons, causes or objectives for effective work behaviour and the harmonising all the motivations and goals in the organisation means to decide what is really correct in a particular managerial situation. It is necessary to decide what parameters should be included into such a decision-making process, what is the goal of motivated behaviour, how this can be most effectively achieved, what participants should be involved in the decision-making process, etc.

Based on the mentioned ideas, the paper is intended to examine the decision making performed in motivating individuals and groups. The aim is to define the theoretical dispositions (literature analysis, comparison, generalisation, and synthesis) and take practical research results as the coherent basis for a perception of motivational process as a decision-making process, respectively, as a set of decision-making processes targeted at influencing work motivation purposefully. On the grounds of searching and confirming defined hypotheses, 
results of questionnaire surveys performed, many other inspirations from other authors dealing with said issues, and own experience in this field, we can define decisionmaking in motivating as multi-criteria and multiplication dynamic process. More specific characteristics of it will be contained in the proposed graphical and verbal model. Both employees and managers can feel higher satisfaction from their work by completing such perceived motivating. Moreover, our findings can serve as a basis for research efforts of other teams.

\section{Decision Making}

Decision making is a process of postulating decisionmaking premises, conditions, restrictions and defining criteria, non-compromising consideration of positives, negatives, possibilities and impossibilities, chances and obstacles of every potential decision-making outcome accepted solution, and determining the 'best' methods of achieving the 'best' solution. "Decision making is one of the basic cognitive processes of human behaviours by which a preferred option or a course of actions is chosen from among a set of alternatives based on certain criteria" (Wang et al., 2004, p. 124). It is a choice among more variants of behaviour that lead to a certain goal achievement (Blazek, 2014, p. 88) or a choice of one course of action from all the available alternatives (Kinard, 1988, p. 138). According to Brooks, the decision making can be described as follows: 1 . Identifying a problem that requires a decision; 2. Gathering information and materials that will help solve that problem; 3 . Generating potential solutions to the problem; 4. Making a rational choice, selecting the best solution, and then implementing it (Brooks, 2003, p. 36).

Hammond et al. point to the positive importance of subjective factors, declaring that good decision making will take into account tangible and intangible aspects of the decision situation ... [and] pertinent facts, feelings, opinions, beliefs, and advice, (1999). Baker et al. present that the decision making should start with the identification of the decision maker(s) and stakeholder(s) in the decision, reducing the possible disagreement about problem definition, requirements, goals and criteria (2001). Although much work has been done to find the optimal solution sets in the different application fields, little is known about how to maintain a decision maker's ability to decide between the alternatives in a solution set (Teppan et al., 2010, p. 112).

"A good decision results in the selection of appropriate goals and courses of action that increase organisational performance; bad decisions result in lower performance" (Jones et al., 1998, p. 167). But the 'ideal best decision' is always only a hypothetical construct, a desired consequence of all efforts, labour and abilities given into the process of decision making. The solution is consideration of the so-called phenomenon of limited rationality of $\mathrm{H}$. A. Simon. According to Simon, rational responses to the environment characterise decision making generally. But at points - often important points rationality fails, and as a consequence there is a mismatch between the decision-making environment and the choices of the decision maker. We refer to this mismatch as 'bounded rationality showing through' (Simon, 1996). In structured situations, at least, we may conceive of any decision as having two components: environmental demands (seen by the individual as incentives; positive or negative) and bounds on adaptability in the given decisionmaking situation. Ideally, an analysis based on rational choice should be able to specify what the environmental incentives are and to predict decisions based on those incentives. What cannot be explained is either random error (even the most rational of us may make an occasional mistake, but these are not systematic) or bounded rationality showing through (Jones, 1999, p. 297).

Thinking with the limited rationality of deciding factors is extraordinarily important especially in the field of systematic motivating. In other words, the fact that the subject of decision-making often decides on the grounds of momentary and ambiguous knowledge influenced by many subjective elements, assumptions, feelings, etc. complicates motivating and makes it a system/sequence of the hardest decision-making processes in management ever. On the other hand, from the viewpoint of the motivation, participative forms of decision-making, whether informal or institutionalized, give employees a certain degree of self-determination and responsibility. They show that the company values and takes seriously the commitment and interest of employees (Benz, 2010, p. 199). Additionally, employees find organisational procedures fair and motivating when they are included in decision-making, any decisions made are explained, and the rules of the process are clearly defined (Kim \& Mauborgne, 2010, p. 183).

\section{Methods}

By combining motivation and efficient decisionmaking, the attention can be from the scientific point of view riveting especially to the possibility of achieving synergies and/or multiplications. The synergy is the change of behaviour and properties of the system due to the influence of creating the interactive effect of its partial subsystems. Such interactions result in the synergic effect, which also characterises the difference from the situation where considered subsystems would function without such interactions (Vodacek \& Vodackova, 2009, p. 40). From the viewpoint of open systems, synergy is the ability of the whole to equal more than the sum of its parts. In a strategyrelated sense, synergy occurs mainly when the distinctive competencies of some departments make significant differences in the ability of other departments to operate effectively (Bartol \& Martin, 1991, p. 66, 200). Shortly: the term synergy refers to instances when the sum of individual contributions exceeds the simple summation of them (Gibson et al., 1997, p. 13).

Multiplications as understood by our research represent certain completion of several combined, suitably balanced and conscientiously connected elements, processes and systems so as to bring, in mutual relations and manageable dynamics, new, previously only hypothetically possible, even unexpected values, qualities, or levels. According to Winkler, the concrete form and especially the resulting shape of the decision making is influenced by 'multiple causes' (2010, p. 19). However, in 
order to achieve desired synergies or multiplication effects (understood as a higher level/quality of synergy), motivation has to be understood and influenced correctly.

\section{Hypotheses and Participants of the Survey}

The survey, or better said the first part of the survey, was performed at the turn of 2012/2013. The basic hypothesis of the survey was the premise that multiplicative effects really exist and can be utilised in the decision making connected with the motivating employees and managers. In order to systemise our efforts we have determined two partial hypotheses: motivation decision making is influenced by a large number of objective as well as subjective factors - motivating is a decisionmaking process (H1). The assumption that motivation is a mosaic of many various elements and influences can be supported by publications of many authors, (e.g. Bakanauskiene et al., 2014; Bender et al., 2012; Frey \& Osterloh, 2010; Benz, 2010; Plaminek, 2010; Grazulis, 2009; Maccoby, 1988; Herzberg, 1986, etc). On the basis of mentioned authors' publications and our experiences as well as results flowed from our previous surveys, the second hypothesis was defined in this way: employees as well as managers are willing to increase their motivation to the complex work effort they perform $(\mathrm{H} 2)$. We decided to perform interviews and with the questionnaire method due to time, financial and logical reasons. The questionnaire for employees contained 20 questions (out of which 4 were open questions) and the questionnaire for managers contained 22 questions (4 open questions).

$\mathrm{N}=1946$ respondents participated in the survey, out of which 1639 were employees (669 men, forming 40,82\% of this group of respondents and 970 women $=59,18 \%$ ) and 307 managers $(170$ men $=55,37 \%$ from the group of managers and 137 women $=44.63 \%$ ). The average age of those interviewed was 38,66 years, in the group of employees 38,09 years $(36,75$ years men and 39,01 years women) and in the group of managers 41,73 years $(41,51$ years men and 41,99 years women). The most numerous group were respondents in the age group 30-40 years $(29,19 \%$ of the group) and in the age group $40-50$ years of age $(28,57 \%)$. With regard to the achieved secondary (high school) education $(42,96 \%)$ and university education $(38,80 \%)$ were dominant. Finally, respondents were told not to put their names on the questionnaire, that data from the study would only serve for scientific purposes and would therefore remain strictly confidential. For statistical purposes we considered the answers without expression of respondents as statistically significant (the question in Table 1: Nature of the factors deciding on how to motivate? The answer without respondents' expression could mean that the company has got a very low level of motivation).

\section{Results of the Survey}

We decided to state the most significant findings with regard to determined hypotheses for the needs of this paper. The first significant area was obtaining opinions of respondents concerned with determining what factors managers when making decisions about how they will motivate their employees consider. This question was also designed on contra-position basis, i.e. we asked employees whether their managers consider quantitative, qualitative or combined (qualitative and quantitative) factors when making decisions about how to motivate them. We asked managers whether they use/respect quantitative, qualitative or combined factors in making decisions about motivating. Results are shown in Table 1. These results show that both groups express as the most preferred exactly the combination of quantitative and qualitative factors at the same time, whereas the frequency of this preference is substantially higher in the group of managers $(62,21 \%)$ than in the group of employees $(43,26 \%)$. The order of preference of quantitative vs. qualitative factors differs as well. Therefore, we can confirm hypothesis $\mathrm{H} 1$, and motivational decision making can be perceived as multicriteria decisional process.

Table 1

Nature of the factors deciding on how to motivate

\begin{tabular}{|c|c|c|}
\hline Nature of preferred factors in the motivational decision making & $\begin{array}{c}\text { Frequency of employees' } \\
\text { expressions } \\
\text { (Number/\%) }\end{array}$ & $\begin{array}{c}\text { Frequency of managers' } \\
\text { expressions } \\
(\text { Number } / \%)\end{array}$ \\
\hline $\begin{array}{l}\text { Quantitative factors (required amount of performance, deadlines tasks, costing, labour } \\
\text { productivity, number of improvements and the amount of savings, expected rewards) }\end{array}$ & $\begin{array}{l}556 \\
33,92 \%\end{array}$ & $\begin{array}{l}44,33 \% \\
14,4\end{array}$ \\
\hline $\begin{array}{l}\text { Qualitative factors (create new value, the expected satisfaction and self-fulfillment, } \\
\text { quality of relationships, the degree of belonging, improve skills, higher self-esteem) }\end{array}$ & $\begin{array}{l}297 \\
18,12 \%\end{array}$ & $\begin{array}{l}70 \\
22,80 \%\end{array}$ \\
\hline Quantitative as well as qualitative simultaneously & $\begin{array}{l}709 \\
43,26 \%\end{array}$ & $\begin{array}{l}191 \\
62,21 \%\end{array}$ \\
\hline Without respondents'expression & $\begin{array}{l}77 \\
4,85 \% \\
\end{array}$ & $2,65 \%$ \\
\hline
\end{tabular}

As the response to rightness of decision making performed when motivating employees, it is important to also search the intensity (strength, level) of motivation felt by employees. Results in Table 2 imply not fully satisfactory situations in this area (especially in the case of employees). It shows that the motivational decision making has some gaps and unused possibilities reflected in lower motivation level (= rather high, average, rather low, low) in comparison with potentially achievable (= high) level. 
Intensity (level) of felt motivation

\begin{tabular}{|c|c|c|c|c|}
\hline \multirow{2}{*}{ Level of felt motivation } & \multicolumn{2}{|c|}{ Frequency of employees' expressions } & \multicolumn{2}{|c|}{ Frequency of managers' expressions } \\
\hline & Number & $\%$ & Number & $\%$ \\
\hline High & 327 & 19,95 & 123 & 40,07 \\
\hline Rather high & 838 & 51,13 & 156 & 50,81 \\
\hline Average & 384 & 23,43 & 26 & 8,47 \\
\hline Rather lower & 56 & 3,42 & 2 & ,65 \\
\hline Low & 26 & 1,59 & & - \\
\hline Without respondents' expression & 8 & ,49 & & - \\
\hline Mean & \multicolumn{2}{|c|}{2,14} & \multicolumn{2}{|c|}{1,7} \\
\hline Std. Dev. & \multicolumn{2}{|c|}{0,845} & \multicolumn{2}{|c|}{0,649} \\
\hline Cronbach's Alpha & \multicolumn{2}{|c|}{0,824} & \multicolumn{2}{|c|}{0,764} \\
\hline
\end{tabular}

$*$ Statistical expression: High $=5$; Rather high $=4 ;$ Average $=3$; Rather lower $=2$; Low $=1 ;$ Without expression $=0$.

From the viewpoint of testing hypothesis $\mathrm{H} 2$ (multiplications in motivation), the gradual fulfilment/nonfulfilment of motivational needs causes higher/lower intensity of motivation. In order to confirm the validity of the said statement it is suitable to present results of two questions applied to managers:

- Proposals for the increase of work motivation,

- Potential percentage increase of the work performance upon improvement of motivational approach (better motivation decisions).
According to the first of these questions, we asked respondents (in open question) to state their proposals concerned with their willingness to improve their motivation and complex work effort. These suggestions would be applied in achieving better and more precise managerial decisions in the field of motivating employees and managers. Table 3 shows the most frequent 12 suggestions of respondents.

Table 3

Respondents' proposals for improving motivational decision making

\begin{tabular}{|c|c|c|}
\hline \multirow{2}{*}{ Proposal } & \multicolumn{2}{|c|}{ Frequency of proposal } \\
\hline & Number of respondents & $\%$ of all respondents \\
\hline Higher financial rewarding & 241 & 12,38 \\
\hline Providing training activities & 55 & 2,83 \\
\hline Building good relationships & 50 & 2,57 \\
\hline Expression higher interest of employees & 32 & 1,64 \\
\hline Providing employee share options & 30 & 1,54 \\
\hline Career growth & 26 & 1,34 \\
\hline Providing need information & 24 & 1,23 \\
\hline Recognition of achievements & 19 & 0,98 \\
\hline Building mutual and open communication & 18 & 0,92 \\
\hline Allowing participate in management and decisions & 11 & 0,57 \\
\hline Providing praise & 11 & 0,57 \\
\hline Providing space for autonomy and independence & 11 & 0,57 \\
\hline
\end{tabular}

According to the second question, it is interesting from the point of view of possible multiplications in motivating, we can examine whether the respondents are willing to improve their work effort (will increase their motivation), if managers improve motivational decisions and measures applied towards them. The results in Table 4 show that up to $72 \%$ of all respondents are willing to increase the level of their efforts. In the next sequence, in the question "In what extent you are willing to increase your effort?" respondents that have indicated they would be able to achieve performance gains (on average) up to $44,92 \%$. The Table hereinafter shows the frequency of performance improvements in desirable increments $(1-25,26-50,51-$ 100 , and 101-150\% of potential effort increase in comparison to present effort).

Table 4

Willingness of respondents to improve their work effort

\begin{tabular}{|c|c|c|c|c|c|c|}
\hline Answer of respondents & \multicolumn{2}{|c|}{ All } & \multicolumn{2}{|c|}{ Employees } & \multicolumn{2}{|c|}{ Managers } \\
\hline Effort increase (yes) & 1398 & $71,84 \%$ & 1197 & $73,03 \%$ & 201 & $65,47 \%$ \\
\hline Without effort increase (no) & 460 & $23,64 \%$ & 362 & $22,09 \%$ & 98 & $31,92 \%$ \\
\hline Without expression & 88 & $4,52 \%$ & 80 & $4,88 \%$ & 8 & $2,61 \%$ \\
\hline \multicolumn{7}{|c|}{ Extent of effort increase (in a case of answer ' $y e s^{\prime}$ )* } \\
\hline Increase of $1-25 \%$ & 311 & $15,98 \%$ & 255 & $15,56 \%$ & 56 & $18,24 \%$ \\
\hline Increase of $26-50 \%$ & 692 & $35,56 \%$ & 585 & $35,69 \%$ & 107 & $34,85 \%$ \\
\hline Increase of $51-100 \%$ & 395 & 20,30 & 357 & $21,78 \%$ & 38 & $12,38 \%$ \\
\hline Mean $(\bar{x})$ & \multicolumn{2}{|c|}{$48,50 \%$} & \multicolumn{2}{|c|}{$46,15 \%$} & \multicolumn{2}{|c|}{$34,68 \%$} \\
\hline
\end{tabular}

*Some of respondents with answer 'yes' did not state the extent of their potential improvement. 
Summarising and connecting results of both mentioned questions, we considered in the analysis the following: proposals for the increase of work motivation were divided into two groups; which were related either to the motivational decision-making process or motivation within other motivation processes. Proposals related to the motivational decision-making process were subsequently divided into subgroups according to previously determined gradation (multiplication) levels. Each group was formed by motivational proposals which best reflect various gradation levels of motivation (these levels will be presented in more detail in the part about practical implications), e.g. $1^{\text {st }}$ level: creative motivation; proposals: for instance, accepting proposals of employees, space for self-action and self-fulfilment; $6^{\text {th }}$ level: satisfaction motivation; proposals: for instance, personal aims, career growth, utilization for humanity, common building. Managers who expressed their proposals for the increase of work motivation were found at a certain level of motivation on the grounds of previously determined gradation levels and motivational proposals defined by them. After thorough categorisation of managers to various levels on the grounds of their preferred motivational tools, we proceeded to the determination of percentage value, which specifies the increase of work motivation upon potential application of determined motivational tools (proposal) at individual gradation levels.

Gradation levels of motivation and potential multiplications

\begin{tabular}{|c|c|c|c|c|c|}
\hline Level & Motivational tools & $\begin{array}{c}\begin{array}{c}\text { Average increase of } \\
\text { performance }(\%)\end{array} \\
\end{array}$ & Mean & SD & $\mathbf{N}$ \\
\hline \multirow{3}{*}{$\begin{array}{c}1 \text { level } \\
\text { creative } \\
\text { motivation }\end{array}$} & Acceptation of suggestions of employees & 36 & \multirow{3}{*}{0,296} & \multirow{3}{*}{0,196} & \multirow{3}{*}{15} \\
\hline & Space for autonomy and self-realization & 29 & & & \\
\hline & $\begin{array}{l}\text { Gathering experiences from other companies, recognizing of other } \\
\text { companies }\end{array}$ & 0 & & & \\
\hline \multirow{8}{*}{$\begin{array}{l}2 \text { level } \\
\text { relationship } \\
\text { motivation }\end{array}$} & Trust and wider range of responsibility, authority, competences & 37 & \multirow{8}{*}{0,297} & \multirow{8}{*}{0,239} & \multirow{8}{*}{58} \\
\hline & Providing the information and improve the communication & 21 & & & \\
\hline & Greater concern for employees and their opinions & 32 & & & \\
\hline & Establish clear rules and objectives & 35 & & & \\
\hline & Respect and esteem, respect of individuality & 30 & & & \\
\hline & Crating good relationships and improve the atmosphere, team building & 26 & & & \\
\hline & Participation in management; decision making and goals & 20 & & & \\
\hline & Mutual and open cooperation & 37 & & & \\
\hline \multirow{6}{*}{$\begin{array}{c}3 \text { level } \\
\text { participative } \\
\text { motivation }\end{array}$} & Establish clear rules and objectives & 35 & \multirow{6}{*}{0,291} & \multirow{6}{*}{0,231} & \multirow{6}{*}{30} \\
\hline & Respect and esteem, respect of individuality & 30 & & & \\
\hline & Crating good relationships and improve the atmosphere, team building & 26 & & & \\
\hline & Participation in management; decision making and goals & 20 & & & \\
\hline & Mutual and open cooperation & 37 & & & \\
\hline & Flexible approach & 15 & & & \\
\hline \multirow{3}{*}{$\begin{array}{c}4 \text { level decision- } \\
\text { making } \\
\text { motivation }\end{array}$} & Moral evaluation and uttering praises, job satisfaction & 58 & \multirow{3}{*}{0,622} & \multirow{3}{*}{0,318} & \multirow{3}{*}{9} \\
\hline & Convinced about the meaning of work and actions, meaningfulness of work & 10 & & & \\
\hline & Develop individual/effective motivational programs & 87 & & & \\
\hline \multirow{5}{*}{$\begin{array}{c}5 \text { level } \\
\text { economic-result } \\
\text { motivation }\end{array}$} & $\begin{array}{l}\text { New management approaches, new managers in company, new system of } \\
\text { management, simplifying the processes }\end{array}$ & 18 & \multirow{5}{*}{0,276} & \multirow{5}{*}{0,273} & \multirow{5}{*}{17} \\
\hline & Develop individual/effective motivational programs & 87 & & & \\
\hline & Valuation of innovative approaches & 10 & & & \\
\hline & Appreciation for work and results & 23 & & & \\
\hline & Realistic and achievable objectives (plans) & 42 & & & \\
\hline \multirow{4}{*}{$\begin{array}{c}6 \text { level } \\
\text { satisfaction } \\
\text { motivation }\end{array}$} & Personal goal & 90 & \multirow{4}{*}{0,314} & \multirow{4}{*}{0,274} & \multirow{4}{*}{24} \\
\hline & Career growth/perspective & 33 & & & \\
\hline & Using for man, common building, creating something valuable & 0 & & & \\
\hline & Appreciation for work and results, qualities & 23 & & & \\
\hline
\end{tabular}

On the grounds of results the multiplication nature of motivation (H2) can be confirmed ( $\mathrm{M}=0,296 ; 0,297$; $0,291 ; 0,622 ; 0,276 ; 0,314)$, as each percentage average for individual levels expresses multiplication of motivation within the framework of motivational decision-making. The total multiplication effect is 2,09-times of motivation of the $6^{\text {th }}$ level as compared to the $1^{\text {st }}$ level. On the grounds of results of the analysis it can be confirmed that motivation at a certain level always draws its strength from the previous type (level) of motivation and if any motivation level at lower positions is not fully satisfied, the manager will in such cases (if the fulfilment of motivation needs also from lower levels would be provided to such manager) manifest higher intensity of efforts and motivational behaviour (as implied by results in Table 5 where SD at a lower level SD =0,196 and at a higher level $\mathrm{SD}=0,318)$.

\section{General Discussion}

Knowledge flows from our survey that both managers and employees continue to be willing to increase their level of motivation in order to achieve better performances - the multiplication nature of motivating was confirmed.

It is obvious that decision-making about influencing motivation or decision-making about the correct motivating should be perceived as multi-criteria qualitative decisionmaking. "Multi-criteria decision-making emerged as a 
hallmark and new branch for decision making processes. It is the study of decision making for problems having multiple objectives" (Liu \& Stewart, 2003). It can be defined as a collection of methodologies for comparison, ranking and selecting multiple alternatives having multiple attributes (Levy, 2005). Multi-criteria decision making is based on the progression of using methods and procedures of multiple conflicting criteria into management planning processes (Umme-e-Habiba \& Asghar, 2009, p. 321).

In a perfect decision-making, decision-maker's influence on final decision lies on information, knowledge, decision-making capacity and other dynamic factors he holds (Wang et al., 2005, p. 1556), and groups of primary economic and social factors (Joksiene \& Zvirblis, 2011, p. 336). One of the typical decisions managers face in motivating employees is these choices: How can we accommodate employees' interests and concerns? (Milkovich \& Boudreau, 1988, p. 800). It means a manager must have some understanding of the important differences that exist between individual employees. He must know how these differences can be identified, to what extent they can be measured, and how they can be related to job performance (Graham, 1991, p. 46) and motivation.

\section{Practical Implications: Qualitative Model of Multi- Content and Multi-Criteria Decision Making}

Motivating always concerns an endless spectrum and chaining of many decision-making processes, where each single one of them concerns multi-criteria issues based on the high level of flexibility of decisive factors. Basic ones from the proposed decision-making are contained in the model (Figure 1). The complex decision making process about/in motivating begins by making decision about the selection of object of motivational decision-making, i.e. by choosing individual or individuals of motivating (Hitka, 2009; Figurska, 2003). The more objects (employees) the manager chooses for motivating, i.e. the manager takes a particular decision about the determination of employees whom s/he will motivate, the more work and motivational processes the manager opens and the more work will wait for him/her. And yet this work will be extraordinarily demanding. On the other hand, if the manager excludes from his/her motivational efforts even one employee, s/he will put the whole motivational effort at risk, whereas the creation of synergy effect and achievement of mutual multiplication effects will be prevented.

It means that it is an absolutely natural decisionmaking process, in which the deciding person wishes to reduce the resulting number of objects as much as possible (in order to have less work), but at the same time knows that s/he should not exclude any object. The decisionmaking conflict interfering with the logic of thinking of the deciding person (manager considering savings) can be seen here, but also/vs. the pro-social, inspirational and creative role of this deciding person (manager - leader motivator). Taking into account the requirements (success criteria) of every one of those roles always increases the number of decision-making criteria.

However, this decision-making is only one of the first steps in the sequence of many other multi-criteria decision- making processes. The following decision-making can be related to the choice whether the deciding person will be satisfied with previous knowledge of motives of motivated objects, i.e. his/her employees, or will insist upon behaviourally correct decision: to perform thorough reanalysis of motives of such objects (Blaskova, 2010; Nakonecny, 1995). This decision-making again consists of formulating assumptions, determination of parameters/ criteria, risks, potential benefits, both short-term (performance) and long-term (efficiency, cognitive, loyalty) of both alternatives and the act of taking the final decision. If $\mathrm{s} /$ he decides for the second option (where such a decision is correct), further decision-making processes open.

It will be important in this induced process to decide by what method or by what methods the analysis of the current motivation and needs will be performed (Hitka, 2009; Hewstone \& Stroebe, 2006; Robbins \& Coulter, 2004). Here another process opens simultaneously (but earlier in time sequence): will one method suffice for the motivational analysis, or will several methods be chosen? If several methods are chosen, then it will be necessary to decide how many methods will be efficient. That represents another decision-making process, in which it has to be considered which particular methods will be the most suitable.

It is obvious that if the subject decides on one of the previous decision-making processes for only one method, some decision-making processes were eliminated (such as making decision about how many methods; which methods; in what time sequence; with what weight of findings in the overall image of the motivational status of the object and so on).

On the other hand, if the subject uses only one method, the risk that $\mathrm{s}$ /he will not obtain truthful reflection of motivational needs, preferences, ideals, interests and attitudes of motivated objects with this method grows. If s/he despite the said risk choses only one method, the result can be the necessity of further (sometimes in the next flow of decision-making sequence) decision-making about possible elimination of such risk (Dewett, 2007; Kozubikova, 2007), as the accepted risk impacts motivation and vice versa (Walsh \& Schneider, 2002). For instance: decision to pay more attention to verification whether the resulting motivational program really sufficiently motivates to desired objectives. This will in turn induce again new decision-making: 1. In what form should the efficiency and directness of the motivational program be monitored? 2. In what time? 3. How many motivational interviews should be made in order to obtain feedback for the motivational program, etc.

Decision about the method/methods of updating knowledge of objects's motives leads to the performance of survey. The decision can be to perform s series of analytical-generating motivational interviews with motivated objects (to discuss face to face with an employee about positive motivation and to define possible methods to influence it). The deciding person can choose as a key method questioning through questionnaire (Kaleta, 2012; Hitka, 2009; Robbins \& Coulter, 2004); or outputs from evaluating interviews, previous motivational interviews (Armstrong, 2007; Kachanakova, 2003), work meetings 
and various discussions, team meetings and so on can be used (Blaskova \& Blasko, 2011), or the method of observation in various situations can be used; usage of a group experiment (Millet et al., 2012; Ariely, 2011; Hewstone \& Stroebe, 2006) or other methods can be decided about. Every chosen method is connected with further decision-making processes: 1. In what form should obtained facts be processed? 2. Should they be presented to employees, and should further intra-group means and tools of motivating be jointly generated? 3. Should the results be presented to superior manager, and together with him/her clarify motivational proposals and decisions?

The subject must in the following decision-making consider/confront the reality of motivational preferences and expectations with regard to possibilities of organisation (Robbins \& Coulter, 2004; Koontz \& Weihrich, 1993), group (team), manager, environment of the organisation, family background of both the subject and object and so on. At the same time, confrontation with every concerned 'partner' represents always separate decision-making processes. Hypothetically, if we wish to compare the reality of expectations with five said partners (whereas for instance the environment of the organisation can include many more comparison partners - customers, competitors, public, banks, self-governments and so on), five decision-making processes have to take place, which should consider to what degree the balance of motivations of all defined partners will be preserved and in each necessary case it will have to be decided whose motivation will be preferred. That means to decide what further aims (decisions) will have to be defined in order to harmonise such motivations.

Further decision-making will be aimed at harmonisation of the long-term (life) motivation of the object with the current motivation of the object (Lisjak, Molden \& Lee, 2012; Nakonecny, 1995; Zanger, 1978). Conflict can arise here, too. How should such conflict be solved? Individually or with the employee? Will it be necessary to make decisions about further (individual) methods of harmonisation of the long-term and/vs. conflicting current motivation? And again, each such decision-making has its parameters/criteria, procedure, dynamics, outcome, which can be satisfactory only to a certain level, and with a certain degree of perceived risk.

In relation to the continued sequence of motivational decision-making, it will be necessary to open and perform at least the following decision-making processes:

- About determination of suitable objectives, goals of motivating (Majtan et al., 2003), such as motivation to quality work and/or creativity and/or loyalty and/or savings and so on.

- About determination of degree of choice or flexibility that can be included in motivating (Milkovich, Boudreau, 1988, p. 800).

- About determination of the share of individual (from the part of the manager) and group (from the part of colleagues) influence and efforts in implementation of the motivational program.

- About the engagement of the motivated object into the process (Wellington, 2011) and implementation of the motivational programme (rate, possibilities, barriers, timidity).

- About determination of the reservoir of motivational tools, with which the motivator/motivators will act on the motivation of the object (Koubek, 2007).

- About determination of the rate of intersection of the previous content (aims, approaches, tools) of the motivational programme with the necessity to include new motivational elements (Blaskova, 2010); for instance: Which elements should be left? Which new elements should be included? How to achieve their compliance/non-conflicting nature? How to solve possible disproportions and controversies?

- About consideration of the competence of motivators to be able to efficiently apply their chosen motivational tools.

- About determination of the development or training of motivational skills (Boxall \& Purcell, 2008; Armstrong, 2007) in case of concerns about lack of motivational competence (both objective and subjective).

- About determination of the content of the initial version of the proposed motivational program (Blaskova \& Hitka, 2011); for instance: Discuss it? How? With whom? Harmonise it?

- About determination of criteria for the assessment of the future efficiency of the programme, such as costs, benefits, side positive and negative effects (Kozubikova, 2007), conflicts, multiplications.

- About specification of the motivational programme and implementation of the same (Priglova, 2007).

- About determination of moments of interim verification of efficiency (In what form? When? How to react? Who to invite in case of trouble?).

- About determination of the mechanism of supplementation and improvement of the motivational programme (By what methods? On the grounds of what signals? When the creation of a new programme rather than specification of the existing one should be chosen? Should HR manager be engaged? Should colleagues be engaged?).

- About performance of motivational interviews (How often? On an individual basis? Should group motivational interview be tried, too?), (Blaskova \& Hitka, 2011).

- About keeping the enthusiasm in fulfilling the motivational program (Robbins \& Coulter, 2004).

- About thorough feedback after achieving all motivation objectives.

- About seeing motivational mistakes and taking corrective measures (Action plan? Training? Discussion with the HR manager?). 


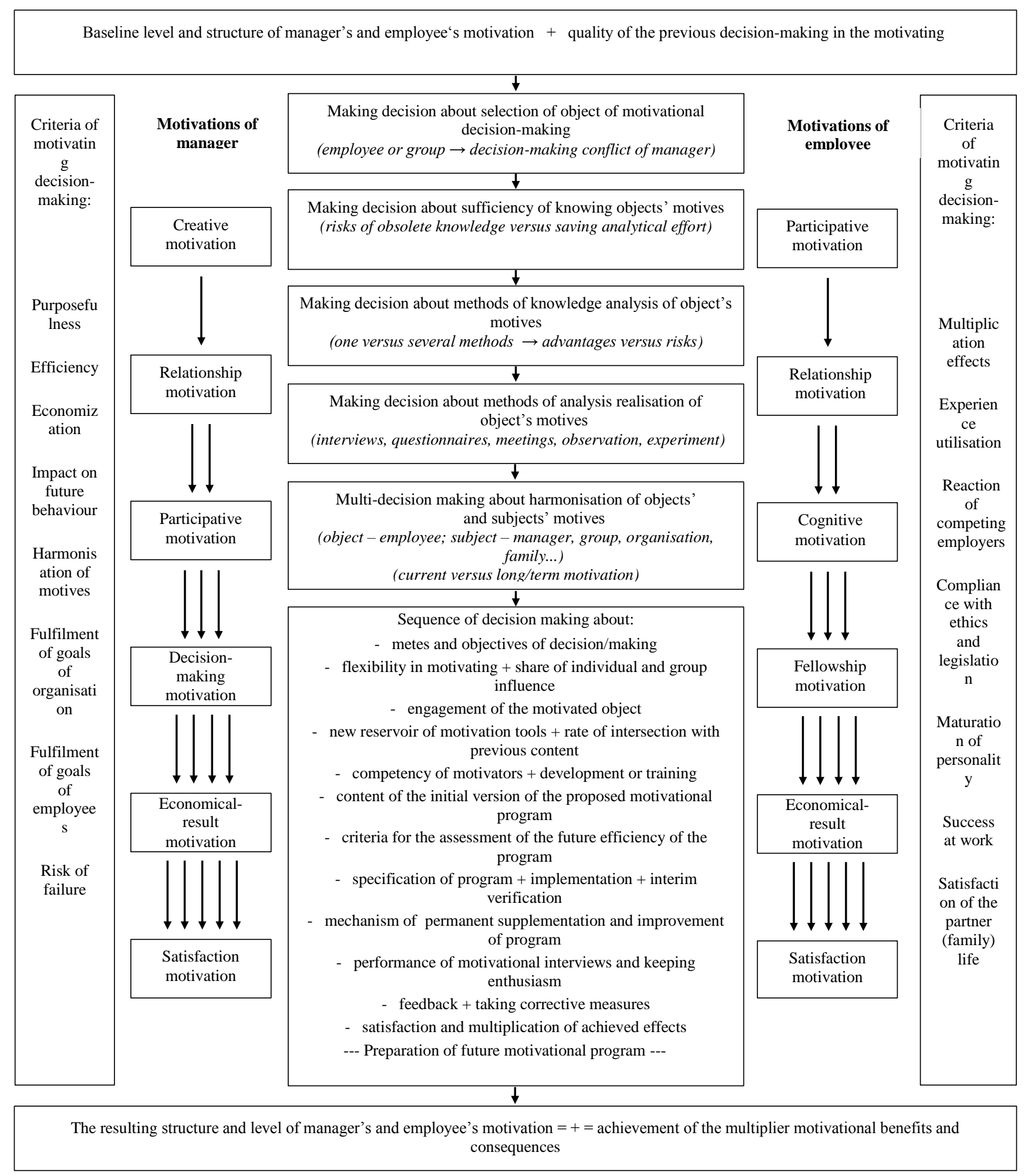

Figure 1. Model of decision making in motivating employees and managers

- About the satisfaction (Wellington, 2011; Armstrong, 2007; Robbins \& Coulter, 2004; Koontz \& Weihrich, 2003, Majtan et al., 2003) and multiplication of achieved effects (transfer of motivation from one motivated employee to another, or transfer of motivation from the motivator to the motivated, respectively).
- About the preparation of future motivational program.

In each one of the said decision-making processes, further (higher) motivation of participants to the motivational decision-making process is gradually influenced and achieved. If the process is performed correctly, the motivation of the motivating manager is increased (gradually multiplied): 
1 level: Creative motivation - manager feels satisfaction from the fulfilment of his/her creative abilities used for making decisions about the choice of objects of motivation, methods of obtaining information about motivational preferences, methods of motivating and harmonising new motivators with the previous ones, etc. These characteristics are similar to Maccoby's understanding of dynamic values (1988).

2 level: Relationship motivation - manager in cooperation with motivated employees (when updating information about their preferences and needs) strengthens his/her relations, trust and sense of fellowship with employees. Content of this level fills the idea of Alderfer's ERG theory (1972) or McClelland's classification of needs (1969).

3 level: Participative motivation - manager consolidates cooperation with other managers and HR experts when discussing correct procedures and participation in the creation of their motivational decisions and engaging such managers to his/her own motivational decisions.

4 level: Decision-making motivation - with every correct motivational decision made in the motivational process the manager feels his/her maturity in the role of deciding person, whereby s/he acquires stronger certainty and enthusiasm for further motivational decisions. These ideas can be supported by Kim \& Mauborgne's characteristics of strategic decision making (1998).

5 level: Economic-result motivation - manager clearly perceives positive consequences of his/her motivational decision-making and efforts, such as the improvement of quality and quantity of performance of employees, growth of the savings rate, growth of the innovations rate etc., but also his/her managerial performance, which jointly induces his/her future motivation to be effective motivator.

6 level: satisfaction motivation - manager realises and obtains through the feedback further signals about his/her motivational results, his/her self-confidence, sense of usefulness and fulfilment of his/her motivational-leading role grows, etc. and thus his/her motivation is stabilised on a long-term basis at a very high, multiplied level. We can relate this level content to the Maslow's needs theory, concretely to author's meta-needs (Maslow, 1970).

Moreover, the motivation of the employee whom the manager strives to motivate is continuously influenced and increased. We can consider for instance the following motivations derived from manager's levels:

1 level: Participative motivation - by engaging the employee into the decision-making about methods of learning about his/her preferences, determination of correct motivators for strengthening of his/her motivation etc. the manager increases employee's participation and sense of partnership in the motivational process.

2 level: Relationship motivation - during communicate his/her needs and ideas for the relationship between the employee and the manager to improve, as well as relationships between employees themselves (when providing information about common group needs).

3 level: Cognitive motivation - the employee is aware of the manager's motivational effort and its impact on his/her own work results, whereby s/he obtains feedback about his/her work behaviour, is aware about his/her strengths and weaknesses and can thus continuously improve and motivate his/her work behaviour.

4 level: Fellowship motivation - the employee is aware of the significance of moral support, sense of fellowship and acceptance (by colleagues as well as manager), what increases his/her motivation to engage with enthusiasm not only in individual tasks but also in joint (team) tasks.

5 level: Economic-result motivation - the employee perceives increased level of his/her results, is aware of his/her contribution to the group, section and organisation (newly created value, growth of work productivity, growth of turnover and profit of the organisation, reduction of customer complaints etc.), what strengthens his/her further work and relationship motivation.

6 level: Satisfaction motivation - awareness of the significance and especially positive consequences of correctly and continuously facilitated motivation (correct motivational decision-making, into which the employee is engaged) very strongly satisfies previous work and social needs of the employee and builds a strong basis for co-participation in every further motivational decision-making and motivated behaviour.

Moreover, each one of the said motivations always draws its strength from the previous type (level) of motivation (the relationship motivation from the participative one or the $2^{\text {nd }}$ level from the $1^{\text {st }}$ level; the cognitive from both the relationship and participative one, i.e. $3^{\text {rd }}$ level from $2^{\text {nd }}+1^{\text {st }}$ level, etc.). That means that connecting and mutual strengthening of the manager's motivation and employee's motivation results in multiplication effects of motivating perceived as a thorough decision-making process. It is obvious from the results of our analyses that if the manager's need is not fully satisfied at a certain level, the increase of his/her motivation to the next level is accompanied with a higher value (Table 5, SD).

\section{Theoretical Implications}

The presented model attempts to cover the content of sequence of decision-making processes when motivating employees. The content of decision-making processes in the model corresponds with the content of decision-making processes presented in literature (Levy, 2005; Wang et al., 2004; Robbins \& Coulter, 2004; Brooks, 2003; Walsh \& Schneider, 2002; Organ \& Bateman, 1991; Cole, 1991; Turban \& Meredith, 1988; etc.).

Each proposed decision-making forms part of the multi-content sequence of decision-making processes in motivating. The existence of following decision-making criteria and requirements can be considered in the presented model (in each decision-making): 
- Purposefulness (Gibb, 2008; Robbins \& Coulter, 2004; Werther \& Davis, 1992).

- Efficiency (Wziatek-Stasko, 2012; Gibb, 2008; Foot \& Hook, 2002; Turban \& Meredith, 1988).

- Economy (Foot \& Hook, 2002; Koontz \& Weihrich, 1993; Organ \& Bateman, 1991; Cole, 1988).

- Impact on future behaviour (Gibb, 2008; Nakonecny, 2005; Organ \& Bateman, 1991).

- Harmonisation of motives (Hitka, 2009; Nakonecny, 1995; Cole, 1988).

- Time currency of motives and tools (Hitka \& Vacek, 2010; Hewstone \& Strobe, 2006)

- Fulfilment of goals of the organisation (Boxall \& Purcell, 2008; Koubek, 2007; Arnold et al., 2007; Robbins \& Coulter, 2004; Wright, 2003; etc.).

- Fulfilment of goals of employees (Luu \& Hattrup, 2010; Mainemelis, 2010; Arnold et al., 2007; Koubek, 2007; Clark, 2003; Amstrong, 2002).

- Risk of failure (Wziatek-Stasko, 2012; Deter \& Burris, 2007; Kozubikova, 2007; Clegg, 2001).

- Extent of utilisation of previous experience (Wziatek-Stasko, 2012; Blaskova \& Blasko, 2011).

- Multiplication effects (Blaskova, 2010).

- Reaction of competing employers (Koubek, 2007).

- Compliance with ethics and legislation (Boxall \& Purcell, 2008; Foot \& Hook, 2002; Koontz \& Weihrich, 1993; Werther \& Davis, 1992).

- Maturation of personality.

Success at work.

Satisfaction of the partner (family) life.

These are indeed numerous criteria. Despite the appearance that our statistical investigation determined relatively low significance of some of the selected motivators (Figure 1), they cannot be excluded in the complex conception of motivation, because every object of motivating, every factor and criterion of motivation in the organisation fulfils also the multiplication role. That means (as already mentioned above) that the whole system of motivating could be unsuccessful without their existence.

Some of the said criteria are to a certain degree in logical conflict with other criteria. For instance, the criterion of purposefulness (to motivate by all available methods in order to achieve the increase/improvement of motivation without regard to financial, time, psychological or factual demands) can be in conflict with the criterion of economy (to choose only such methods of motivating that are not financially demanding). In this case there actually occurs a space for another new decision-making process, the substance of which will be to decide which criteria are more important and will be preferred for a certain period of time (however this shall only be a temporary preference of certain elements and full individualistic and multiplication conception of the motivation must be applied as soon as possible) in the whole decision-making complex. According to Kachanakova, similar problems occur also in the case of selection of new employees (2007, p. 88).

The above said implies that motivational decisionmaking is always a multi-content and multi-criteria system of decision-making processes. The success of such processes is based on the flexibility of motivation subjects, objects, conditions inside the organisation as well as within close environment of the organisation. It can therefore be derived that multi-criteria nature is closely related to flexibility. Flexibility is a necessary precondition for multi-criteriality. At the same time, multi-criteriality of previous decision-making processes is a source of constant strengthening of the future flexibility, creativity and engagement of all participants in the motivational decisionmaking: subjects (managers, HR managers) and objects (employees).

\section{Limitations and Further Research}

Full generalisation of obtained survey results and the proposed model arising from it can be to a certain degree influenced by geographical-cultural locality in which the survey took place, as well as by the time period of survey performance. Obtained sociologic results are from the geographical-cultural point of view often specific and characteristic (valid) just for the region (continent, country) where the survey took place. Psychic processes, i.e. emotions, motivation, experience and so on can be specific with regard to the continent, cultural groups etc. (Kassin, 2012; Scherer \& Wallbot, 1994).

Similarly, the on-going financial crisis, and especially the showing social crisis, can mean a certain specification of our results (in comparison with e.g.: Lisiak et al., 2012; Joksiene \& Zvirblis, 2011; Hitka \& Vacek, 2010; Hinkin \& Schriesheim, 2009). Companies have exactly in this period of time an excellent space for application of just those motivational tools and taking those decisions that are not too financially demanding. That, to a small degree, contravenes results of our survey from 2006 (performed with a sample of $\mathrm{N}=950$ respondents): the current survey (2012/2013) confirmed the application of praise as much as $41,42 \%$ respondents (financial bonuses were confirmed by $43,06 \%$ respondents). Granting of praise was confirmed in 2006 by more respondents than the utilization of financial bonuses (42,07 \%), (Blaskova et al., 2006, p. 40).

Further continuation of surveys in the area of personality, motivation, decision-making etc. performed or planned around the world will be important. Promising results are expected especially from neurolinguistic programming and related research. The application of these points of view on the area of human and work motivation will be certainly beneficial.

\section{Conclusion}

Facts said in the previous text imply that motivational decision-making is always a multi-content and multicriteria system of decision-making processes. Success of such processes is based on the flexibility of motivation subjects, objects, conditions inside the organisation and within close environment of the organisation. It can be derived that with regard to motivating the human potential, the decision-making flexibility is always closely related to multi-criteriality. Flexibility is a necessary precondition of multi-criteriality. At the same time, multi-criteriality, correctly applied in all previous decision-making processes, is a source of constant strengthening of future flexibility, creativity and engagement of all participants to 
motivational decision-making: subjects (managers, HR managers) and objects (employees). The maturity of motivators and quality of their motivational decision making is closely related to the sense of necessary personal and social responsibility. "Social responsibility is by no means managerial news or discovery. It is a mature approach to the economic life, employees, work, nature; especially it is a concept incarnating people and intended for people" (Tokarcikova \& Ponisciakova, 2012, p. 275). It can be metaphorically said that the personal responsibility of employees is to perform work pursuant to requirements of the employer. Their social responsibility is to contribute by their work behaviour to create a favourable and helpful work environment (motivating atmosphere) also for other employees and managers, and jointly contribute to the progress of the organisation. The personal responsibility of managers is to cultivate their own motivation and conscientiously perform all managerial functions and roles. Their social responsibility is to cultivate motivation of their employees and other managers and thereby systematically confirm the status of the organisation as a successful economic as well as exemplary social subject. This is all necessarily facilitated by previously built motivation of employees and managers, and especially is and will be emphasised by the quality of motivational decision-making processes.

\section{Acknowledgement}

Paper is a result and it has been supported by Scientific Grant Agency of Education Ministry of Slovak Republic, grant VEGA No 1/0890/14 Stochastic Modelling of Decision Making Processes in Motivating Human Potential.

\section{References}

Alderfer, C. (1972). Existence, Relatedness and Growth: Human Needs in Organizational Settings. New York: Free Press. Ariely, D. (2011). Jak je draha intuice (The upside of irrationality). Prague: Prah.

Armstrong, M. (2007). Rizeni lidskych zdrojů (Human resource management). $9^{\text {th }}$ edition. Prague: Grada.

Armstrong, M. (2002). Rizeni lidskych zdrojů (Human resource management). $8^{\text {th }}$ edition. Prague: Grada.

Arnold, J. et al. (2007). Psychologie prace pro manazery a personalisty (Psychology of Work for Managers and HR Specialists). Brno: Computer Press.

Bakanuskine, I., Zalpyte, L., \& Vaikasiene, J. (2014). Employer's Attractiveness: Employees' Expectations vs. Reality in Lithuania. Human Resources Management and Ergonomics, 8(1), 6-20.

Baker, D., Bridges, D., Hunter, R., Johnson, G., Krupa, J., Murphy, J., \& Sorenson, K. (2001). Guidebook to DecisionMaking Methods, WSRC-IM-2002-00002. USA: Department of Energy.

Bartol, K. M., \& Martin, D. C. (1991). Management. New York: McGraw-Hill.

Bender, M., Woike, B. A., Burke, Ch. T., \& Dow, E. A. A. (2012). The Relationship between Implicit and Explicit Motives, Goal Pursuit, and Autobiographical Memory Content during a Diary Study. Journal of Research in Personality, 46(4), 374-383. http://dx.doi.org/10.1016/j.jrp.2012.03.005

Benz, M. (2010). Management of the Unwritten - How You Can Improve Employment Relationships through Participation and Communication. Frey, B. S., Osterloh, M. (eds.). Successful Management by Motivation. (pp. 191215). Berlin: Springer.

Blaskova, M. (2010). Creative Proactive-Concluding Theory of Motivating. Business: Theory and Practice, 11(1), 39-48. doi: 10.3846/btp. 2010.05.

Blaskova, M., \& Blasko, R. (2011). Decision Taking in Motivating Employees. Human Resources Management and Ergonomics, 5(1), 19-32.

Blaskova, M. et al. (2006). Riadenie a rozvoj vysokokvalifikovaného l’udského potencialu (Management and Development of High-qualified Human Potential). Zvolen: Technical University in Zvolen.

Blaskova, M., \& Hitka, M. (2011). Model riadenia pracovnej motivacie v priemyselnych podnikoch (Model of work motivation management in industrial enterprises). Zvolen: Technical University in Zvolen.

Blazek, L. (2014). Management. Organizovani, rozhodovani, ovlivnovani (Management. Organising, Decision Making, Influencing). $2^{\text {nd }}$ edition. Prague: Grada.

Boxall, P., \& Purcell, J. (2008). Strategy and Human Resource Management. $2^{\text {nd }}$ edition. London. Palgrave Macmillan.

Brooks, I. (2003). Organisational Behaviour. 2nd edition. Harlow: Pearson Education.

Clark, R. E. (2003). Fostering the Work Motivation of Individuals and Teams. Performance Improvement, 42(3), 21-29 http://dx.doi.org/10.1002/pfi.4930420305

Clegg, B. (2001). Instant Motivation. London: Kogan Page, Ltd.

Cole, G. A. (1991). Management. Theory and Practice. $3^{\text {rd }}$ edition. London: D. P. Publications, Ltd.

Cole, G. A. (1988). Personnel Management. Theory and Practice. $2^{\text {nd }}$ edition. London: D. P. Publications, Ltd.

Deter, J. R., \& Burris, E. R. (2007). Leadership Behavior and Employee Voice: Is the Door Really Open? Academy of Management Journal, 50(4), 869-884. http://dx.doi.org/10.5465/AMJ.2007.26279183 
Dewett, T. (2007). Linking Intrinsic Motivation, Risk Taking, and Employee Creativity in an R\&D Environment. $R \& D$ Management, 37(3), 197-208. http://dx.doi.org/10.1111/j.1467-9310.2007.00469.x

Figurska, I. (2003). Przestrzenne aspekty rynku pracy na przykładzie Pomorza Srodkowego (General Aspects of Job Market in Pomorze Srodkowe). Słupsk: Wyzsa Szkola Zarządzania w Słupsku

Foot, M., \& Hook, C. (2002). Personalistika (Personnel management). Prague: Computer Press.

Frey, B. S., \& Osterloh, M. (2010). Successful Management by Motivation. Berlin: Springer.

Gibb, S. (2008). Human Resource Development. $2^{\text {nd }}$ edition. New York: Palgrave MacMillan.

Gibson, J. L., Ivancevich, J. M., \& Donnelly, J. H. (1997). Organizations: Behavior, Structures, Processes. Boston: Irwin/McGraw-Hill.

Graham, H. T. (1991). Human Resources Management (Revised by R. Bennett). $6^{\text {th }}$ edition. London: Pitman Publishing.

Grazulis, V. (2009). David McClelland's 3-need Theory and Its Place in Modern-day Employee Motivation. Borkowski, S., Blaskova, M., Hitka, M. (eds.). Toyotarity: Motivation Features of Managers. (pp. 132-141). Dnipropetrovsk: Yurii Matovetsky.

Grusec, J. E., Lockhart, R. S., \& Walters, G. C. (1990). Foundations of Psychology. Toronto: Copp Clark Pitman.

Hammond, J. S., Keeney, R. L., \& Raiffa, H. (1999). Smart Choices: A Practical Guide to Making Better Life Decisions. New York: Broadway Books.

Herzberg, F. (1986). One More Time: How Do You Motivate Employees? Harvard Business Review, September-October, 5-16.

Hewstone, M., \& Stroebe, W. (2006). Socialni psychologie (Social psychology). Prague: Portal.

Hinkin, T. R., \& Schriesheim, CH. A. (2009). Performance Incentives for Tough Times. Harvard Business Review, 3.

Hitka, M. (2009). Model analyzy motivacie zamestnancov vyrobnych podnikov (Model of Employees' Motivation Analysis in Production Companies). Zvolen: Technical University.

Hitka, M., \& Vacek, V. (2010). Changes in Motivation of Workers in Production in a Production Company as a Result of the Economic Crisis. Proceeding of international conference Human Potential Development: Search for Opportunities in the New EU States. Vilnius: Mykolas Romeris University.

Joksiene, I., \& Zvirblis, A. (2011). Ekonominiu ir socialiniu veiksniu įtakos investiciniams fondams vertinimo principai (Principles of evaluation of the impact of economic and social factors on investment funds). Current Issues of Business and Law, 6(2), 335-348. http://dx.doi.org/10.5200/1822-9530.2011.19.

Jones, B. D. (1999). Bounded Rationality. Annual Reviews of Political Sciences, 2, 297-321.

Jones, G. R., George, J. M., \& Hill, Ch. W. L. (1998). Contemporary Management. Boston: Irwin/McGraw-Hill. http://dx.doi.org/10.1146/annurev.polisci.2.1.297

Kachanakova, A. (2007). Riadenie l'udskych zdrojov (Human Resource Management). Bratislava: Sprint, vfra.

Kaleta, M. (2012). Fluktuacia zamestnancov v podnikoch SR a jej mozné eliminacie (Fluctuation of Employees in Enterprises of SR and Its Possible Eliminations). Banska Bystrica: University of Matej Bel.

Kassin, S. (2012). Psychologie (Psychology). Brno: CPress.

Kim, W. C., \& Mauborgne, R. (1998). Procedural Justice, Strategic Decision Making, and the Knowledge Economy. Strategic Management Journal, 19, 323-338. http://dx.doi.org/10.1002/(SICI)1097-0266(199804)19:4<323::AIDSMJ976>3.0.CO;2-F

Kinnard, J. (1988). Management. Lexington: D. C. Heath and Company.

Koontz, H., \& Weihrich, H. (1993). Management. Prague: Victoria Publishing.

Koubek, J. (2007). Rizeni lidskych zdrojů (Human resource management). $4^{\text {th }}$ edition. Prague: Management Press.

Kozubikova, Z. (2007). Vybrané problémy identifikacie rizik (Selected Problems in Risk Identifying). Proceedings of 5th International Conference Direct Foreign Investments. (pp. 275-278). Kunovice: European Polytechnics Institute.

Levy, J. K. (2005). Multiple Criteria Decision Making and Decision Support Systems for Flood Risk Management. Munchen: Springer-Verlag.

Lisiak, M., Modeln, D. C., \& Lee, A. Y. (2012). Primed Interference: The Cognitive and Behavioral Costs of an Incoungruity between Chronic and Primed Motivational Orientations. Journal of Personality and Social Psychology, 102(5), 889-909. http://dx.doi.org/10.1037/a0027594

Liu, D., \& Stewart, T. J. (2003). Integrated Object-oriented Framework for MCDM and DSS Modeling. Elsevier.

Luu, L., \& Hattruo, K. (2010). An Investigation of Country Differences in the Relationship between Job Satisfaction and Turnover Intentions. Applied H.R.M. Research, 12(1), 17-39.

Maccoby, M. (1988). Warum Wir Arbeiten: Motivation als Führungsaufgabe. Frankfurt /M. 
Mainemelis, Ch. (2010). Stealing Fire: Creative Deviance in the Evolution of New Ideas. Academy of Management Review, 35(4), 558-578.

Majtan, M. et al. (2003). Manazment (Management) Bratislava: Sprint, vfra.

Maslow, A. H. (1970). Motivation and Personality. New York: Harper \& Row.

McClelland, D. C., \& Winter, D. C. (1969). Motivating Economic Achievement. New York.

Milkovich, G. T., \& Boudreau, J. W. (1988). Personnel/Human Resource Management. A diagnostic Approach. $5^{\text {th }}$ edition. Homewood, Illinois: BPI, Irwin.

Millet, K., Lamey, L., \& Van den Bergh, B. (2012). Avoiding Negative vs, Achieving Positive Outcomes in Hard and Prosperous Economic Times. Organizational Behavior and Human Decision Processes, 118(2), $179-188$.

Nakonecny, M. (2005). Socialni psychologie organizace (Social psychology of organization). Prague: Grada.

Nakonecny, M. (1995). Psychologie osobnosti (Psychology of personality). Prague. Academia.

Organ, D. W., \& Bateman, T. S. (1991). Organizational Behavior. $4^{\text {th }}$ edition. Homewood: Irwin.

Plaminek, J. (2010). Tajemstvi motivace. $2^{\text {nd }}$ edition. Praga: Grada.

Priglova, H. (2007). Analyza motivacnej struktúry a motivacnych preferencii zamestnancov v podniku (Analysis of Employees' Motivation Structure and Motivation Preferences in a Company). Manazment $v$ teórii a praxi (Management in Theory and Practice), 3(1/2), 12-19.

Robbins, S. P., \& Coulter, M. (2004). Management. Prague: Grada Publishing.

Scherer, K. R., \& Wallbot, H. G. (1994). Evidence for University and Cultural variation of Differential Emotion Response Patterning. Journal of Personality and Social Psychology, 66, 310-328.

Simon, H. A. (1996). The Sciences of the Artificial. $3^{\text {rd }}$ edition. Cambridge, MA: MIT Press.

Teppan, E. Ch., Friedrich, G., \& Felfernig, A. (2010). Impacts of Decoy Effects on the Decision Making Ability. 12th IEEE International Conference on Commerce and Enterprise Computing. doi 10.1109/CEC.2010.30, 112-119.

Tokarcikova, E. \& Ponisciakova, O. (2012). Spolocensky zodpovedni zamestnanci (Socially Responsible Employees). Business Environment Horizons. (pp. 275-281).

Turban, E., \& Meredith, J. R. (1988). Fundamentals of Management Science. $4^{\text {th }}$ edition. Homewood, Illiniois: BPI, Irwin,

Umm-e-Habiba, \& Asghar, S. (2009). A Survey on Multi-Criteria Decision Making Approaches. International Conference on Emerging Technologies 2009 (pp. 321-325).

Vodacek, L., \& Vodackova, O. (2009). Synergie v modernim managementu (Synergies in Modern Management). Prague: Management Press.

Walsh, K. R., \& Schneider, H. (2002). The Role of Motivation and Risk Behaviour in Software Development Success. Information Research, 7(3).

Wang, Y., Liu, D., \& Ruhe, G. (2004). Formal Description of the Cognitive Process of Decision Making. Proceedings of the Third IEEE International Conference on Cognitive Informatics 2004. (pp. 124-130).

Wang, W., Chen, J., \& Da, Q. (2005). Optimal Allocation of Decision Weights and Decision-Making Proces of Knowledge-Based Enterprise Organism. IEEE International Conference on Systems, Man and Cybernetics 2005. (pp. 1556-1561).

Wellington, P. (2011). Effective People Management. London: Kogan Page.

Werther, W. B., \& Davis, K. (1992). Lidsky faktor a personalni management (Human Factor and Personnel Management). Prague: Victoria Publishing.

Winkler, I. (2010). Contemporary Leadership Theories. Berlin: Springer-Verlag Berlin Heidelberg.

Wright, B. E. (2003). Toward Understanding Task, Mission and Public Service Motivation: A Conceptual and Empirical Synthesis of Goal Theory and Public Service Motivation. Proceedings of 7th National Public Management Research Conference, October 9-11, 2003. Washington, D.C.: Georgetown University.

Wziatek-Stasko, A. (2012). Diversity Management ako stratégia riadenia ludskych zdrojov v súcasnych organizaciachimplikacie pre motivovanie zamestnancov (Diversity Management as A Human Resource Management Strategy in Contemporary Organizations - Implications for Motivating Employees). Banska Bystrica: University of Matej Bel.

Zanger, R. (1978). Managing Guaranteed Employment. Harvard Business Review, May/Jun 1978, 56(3), $103-115$.

The article has been reviewed.

Received in November, 2014; accepted in December, 2015. 